\title{
昭和前期の東京の町家形式とそれに対する市街地建築物法の 影響（中央区を例として）
}

\author{
STYLES OF THE TOWN HOUSE IN TOKYO DURING THE PERIOD \\ 1926-1946 AND THE INFLUUENCE OF URBAN BUILDING \\ CODE ON IT (THE CASE OF CHUOO WARD)
}

\author{
江面嗣 人* \\ Tuguto EZURA
}

\begin{abstract}
Town houses in early showa period (1926-1936) were built, not only in the traditional style of DASIGETA ZUKURI, but in the new styles: In one of the new styles, the facade of houses were made flat and covered with copperplates.

I intend to describe the changes of town houses and the reasons for these changes by conduct. ing an investigation of the houses in Chuo Ward and by checking the records and statistics of houses and the building code in that period. Through these analysis, I make it clear that Urban Building Code (SIGAICHI KENCHIKUBUTU HO) stated in 1919 influenced the lack of development of the third floor and the increase of the number of town house with flat facad.
\end{abstract}

Keywords : town house, 'Tokyo, urban building code, building line, floor plan, facade

\section{I.はじめに}

江戸・東京の幕末から大正期に至るまでの町家につい ては，先に佃島の住居の類型と変遷を明らかにしだ”。 しかし，その後の昭和期の変化については，佃島では例 証が少なく，明らかにすることができなかった。

現在の東京には，関東大震災以降，昭和前期にかけて 建られた町家がかなり残存しているう。これらは，それ までの出桁造の形式だけでなく，正面を銅板張りにした 新しい形式のものも建てられている。これらの新しい町 家については，これまで間取等を含む詳しい検討がされ ていない。

本稿では，中央区における大正後期から昭和前期まで に建てられた住居の実测調査 ${ }^{3}$ をとに，当時の記録・ 統計や建築法規を検討し，この時期の町家の形式がそれ 以前のものと比較してどのように変化したのか, また, その変化の主な理由はなにか，などを検討した4)。

以下では，まず調査地域の歴史的背景について述へ， 次に調查住居の特色についてまとめた。そして，その主 要な変化,すなわち, 階数の増加， 2 階の続き間座敷の 発達， 3 階建住居の間取について述へ，最後に当時の町 家に対する市街地建築物法や仮設建築物法の影響につい
て考察を行う。

\section{II. 調査地域の概要}

中央区は，旧日本橋区と旧京橋区が昭和 22 年に合併 されてできた区で，その名が示す通り東京市の旧市域の 中央に位置している。江戸時代には江戸城の東側に接し ており，多くの藩邸が並ぶと同時に，商人や職人の多く 住む地区でもあった。従って，明治期以降は丸の内・銀 座通り地区を中心に近代的なビルが多く建てられたが, 隅田川に近い築地・人形町などの東側の地区には，江戸 時代からの伝統的な庶民住居が多く存在した。。

し加し，大正 12 年の関東大震災（以後単に「震災」 と呼ぶ）によって，中央区の佃島以外の全ての地区が火 災に遭い，木造家屋のほとん亡゙を焼失してしまった。ま た，第二次大戦の空襲でもかなりの地区が被災し，多く の家屋を失った。

そのような中で，築地や月島等の戦災で焼け残った地 区には，現在でも震災以降から昭和 20 年までに建てら れた住居が, 比較的多く残存している。従って, 中央区 全体では，江戸末期・明治・大正・昭和期の家屋が，区 全体に分散してはいるが，時代的に連続して存在してい

本稿の一部は昭和 62 年の日本建築学会大会学術謢演梗概集に発表している。

* 千葉経済高校教諭 (千葉大学大学院生). I修 Teacher of Chibakeizai High School (Graduate Student of Chiba Univ. ), M. Eng. 
表一1＼cjkstart調查住居の主要特徵に関する一覧表

\begin{tabular}{|c|c|c|c|c|c|c|c|c|c|c|}
\hline 住居番 & 所在地 & 建築年代 & 構造穊要 & 正面搆迢 & 数地状 & 間口X奥行(間) & 当初住人職種 & 專／併 & 独／長 & 女中部屋 \\
\hline 住居 1 & 築地二丁目 & 昭和 2 年 & 木遗 $2 \mathrm{~F}$ & 下見 & 表通り & $5.5 \times 4$ & （会社役員） & 専 & 独 & 有 \\
\hline 住居 2 & 築地二丁目 & 昭和 $4 \sim 5$ 年 & 木造 $2 \mathrm{~F}$ & 出标 & 衰通り & $4 \times 6.5$ & 桖節屋 & 併 & 独 & 有 \\
\hline 住居 3 & 箱地二丁目 & 昭和 4 年 & 木造 $2 \mathrm{~F}$ & 下見 & 夏通り & $5 \times 6 ?$ & 質屋 & 併 & 独 & 有 \\
\hline 住居 4 & 築地一丁目 & 昭和 2 年(?) & 木造 $4 \mathrm{~F}$ & モルタル & 表通り & $2 \times 4.5$ & 床屋 & 併 & 独 & 無 \\
\hline 住居 5 & 榮地二丁目 & 昭和 $3 \sim 4$ 年 & 木逼 $2 \mathrm{~F}$ & 銅板 & 表通り & $5.5 \times 8$ & 医院 & 併 & 独 & 有 \\
\hline 住居 6 & 築地六丁目 & 昭和 2 年 & 木适 $2 \mathrm{~F}$ & 出樎 & 衰通り & $2.5 \times 6$ & （海産物間屋） & 尃 & 独 & 無 \\
\hline 住居 7 & 築地六丁目 & 昭和 13 年 & 木遗 $2 \mathrm{~F}$ & 下見 & 患通り & $4 \times 5.5$ & (魚仲買人) & 専 & 独 & 無 \\
\hline 住居 8 & 畾地六丁目 & 昭和 $6 \sim 7$ 年 & 木造 $2 \mathrm{~F}$ & 銅板 & 坟通り & $2 \times 3.75$ & 勤め人 & 専 & 8 軒長 & 無 \\
\hline 住居 9 & 地六丁目 & 昭和 21 年 & 木迢 $2 \mathrm{~F}$ & 下見 & 裹通り & $3 \times 6$ & （魚問屋） & 専 & 独 & 無 \\
\hline 住居10 & 築地七丁目 & 昭和 2 年 & 木造 $3 \mathrm{~F}$ & 銅板 & 表。角 & $4.9 \times 2.8$ & 米・瀬戸物屋 & 併 & 独 & 無 \\
\hline 住居11 & 築地七丁目 & 昭和初年 & 木造 3 F & 銅板 & 表通り & $2.25 \times 4.5$ & 勤め人 & 専 & 3軒長 & 無 \\
\hline 住居12 & 築地七丁目 & 昭和 5 年 & 木造 $2 \mathrm{~F}$ & 出桁 & 裏通り & $3.5 \times 5$ & 整箷問屋 & 件 & 独 & 無 \\
\hline 住居13 & 地七目 & 昭和 $7 \sim 8$ 年 & 木适 $3 \mathrm{~F}$ & 出枌 & 表通り & $3.5 \times 5$ & 不明 & 併 & 独 & 䑨 \\
\hline 住居14 & 築地七丁目 & 昭和 6 年 & 木道 $2 \mathrm{~F}$ & 下見 & 裏通り & $7 \times 5.4$ & （魚仲買人） & 曹 & 独 & 無 \\
\hline 住居15 & 入船一丁目 & 昭和 4 年 & 木遗 3 F & $1 \mathrm{~F}$ 銅 $2 \mathrm{~F}$ 出标 & 表。角 & $3 \times 6.5$ & 米屋 & 併 & 独 & 然 \\
\hline 住居16 & 淃二丁目 & 昭和 2 年 & 木造 2 F & モルタル & 表通り & $5 \times 5$ & 洋菓子問屋 & 件 & 独 & 然 \\
\hline 住居17 & 湊一丁目 & 昭和 $3 \sim 4$ 年 & 木2·RC3F & 下見·外 & 表通り & $9.5 \times 5.5$ & （区会議員） & 専 & 独 & 有 \\
\hline 住居18 & 虾殸一丁目 & 昭和 3年 & 木造 3F & 絧板 & 表通り & $2.5 \times 4.5$ & 魚屋 & 併 & 独 & 船 \\
\hline 住居19 & 人形町一丁目 & 昭和初年 & 木造 $2 \mathrm{~F}$ & 銅板 & 表通り & $2.25 \times 8$ & 呉服問屋 & 併 & 独 & 艒 \\
\hline 住居20| & 月島四丁目 & 昭和14年 & 木造 3 F & 仪,3F下見 & 表。角 & $4.75 \times 6.75$ & ミルクホール & 併 & 独 & 然 \\
\hline 住居21 & 佃二丁目 & 昭和 6年 & 木造 $2 \mathrm{~F}$ & 出桁 & 表通り & $3.5 \times 4.5$ & 雑貨屋 & 併 & 独 & 璑 \\
\hline 任居22 & 佃二丁目 & 昭和 5～10年 & 木造 $2 \mathrm{~F}$ & 出桁 & 表通り & $2 \times 4.75$ & 不明 & 併 & 2 軒長 & 舡 \\
\hline 住居23 & 佃一丁目 & 大正11年 & 木違 $2 \mathrm{~F}$ & 出标 & 婁通り & $3.5 \times 5$ & （魯仲買人） & 専 & 独 & 桶 \\
\hline
\end{tabular}

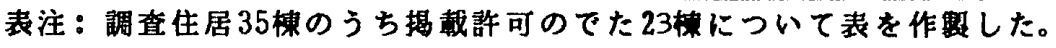

\section{るということができる。}

建築法規についてみると，まず，大正 8 年に制定され た市街地建築物法の施行により，旧日本橋区の全域及び 旧京橋区のほとんどが商業地域の指定を受け，両区の主 要道路の両側は防火区域に指定された ${ }^{5)}$ 。震災後の帝都 復興の区画整理事業では，佃島を除いた旧日本橋区と旧 京橋区が対象地区となり，区内の道路は整備され，敷地 形状もそれに伴い大きく変更された。

\section{III. 調査住居の概要}

\section{(1) 調查の概要}

今回の調査は, 昭和 20 年以前に建てられた中央区全 域の木造住居を対象として, 一次調查で約 60 棟の住居 を選び，二次調査でその中の実测の可能な 35 棟の住居 について調查したものである ${ }^{6 !}$ 。調査住居は主に，築地・ 月島周辺に分布し，建築年代は明治初年から昭和 21 年 頃までに分布している。調查は昭和 61 年 6 月から同 62 年 3 月まで行った。今回, 実測のできた住居は表一 1 に
示す通りである。

\section{（2）調查した住居の特色}

調査した住居は表一1 や間取により分析する上，次の 特色があると考えられる。すなわち，

(1) 建築年代は昭和 2 年から 5 年にかけてのものが多 い。

(2) 階数は 2 階建，3 階建が主で，4階建のものが 1 棟 あり，平屋は見られない。

(3) 正面の構造・意匠は伝統的な出桁造と，正面の壁面 をフラットに揃えて銅板張りとしたものが多い。

(4) 建物の間口・奥行の寸法は一定せず，その 1 階平面 の形式も多様である。間口が奥行より広い住居も見られ た。

(5)自宅で商業を営むための表士間をもつ併用住居が過 半数を占めている。

(6) ほとんどの住居が 2 階に座敷をもっている。廊下を もつ住居が多い。

(7) 建て主の職種は一定していないが，魚介類の売買に 
従事する者が多い。

上のような特色がみられる理由について次のように考 えられる。

1) 建築年代は，昭和 2 年から 5 年にかけてのものが多 い（23 棟中 15 棟）という結果になった。これは主に, 佃島以外の調査地区のほとん亡゙の住居が震災による火災 で焼けており，ようやくこの頃になって住居が建ち始め たことによると考えられる。

特に, 調查住居の数の多い築地地区では，帝都復興に 伴う区画整理が昭和 2 年に終了している7)。従って, 昭 和 2 年以降に，区画整理された教地に新たな住居が建て

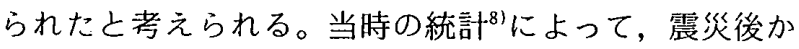
ら昭和 10 年までの旧京橋区の新築家屋棟数を調べてみ ると, 昭和 3 年がピークになっている。東京市全体につ いても，震災被災地区における新築棟数は，昭和元年か ら増加し始め, 昭和 3 年に約 6 干棟とピークになり, そ の後徐々に減少している ${ }^{9)}$ 。帝都復興による区画整理は, 大正 13 年より開始され, 地区によって進展度に差はあ るが，区画整理及び既存建築物の移転は，昭和 3 年末に は $97.7 \%$ が終了しており，昭和 4 年 9 月には $99.9 \%$ が終了し，一応の完了をみている ${ }^{10)}$ 。

この区画整理の終了時期は，各区において多少の差は みられるものの, 中央区の築地地区及び東京市全体で新 築棟数の増加時期とほぼ重なりがみられるのは, 一忍の 因果関係があるものと考えることができるい”。

2）階数については，調查地域には佃島を始めとして平 屋の住居が何棟か存在するが，2 階建の住居に比較する と極めて少ない。これは，ある時期に階数の増加が顕著 になったためと思われるが, この点については次の章で 詳しい考察を行いたい。

3）正面の構造・意匠については, 伝統的な形式として 出桁造が見られ，新たな形式として正面の壁面をフラッ

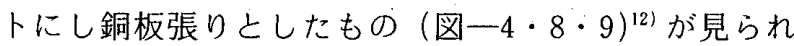
た。この出桁造については前稿 ${ }^{13)} て ゙$ 解説をしたので説明 を省くが，後者の形式についてはこれまでに詳しい考察 がされておらず，当時の建築法規との関連が深いと思わ れるので，後章で詳しく考察をするこどにしたい。

4）敷地形状については, 江戸時代のように, 間口に対 して奥行きの深い形ではなく，震災後の区画整理によっ て, 敷地形状が大きく変更された。正方形に近い敷地形 状が作られ ${ }^{14)}$ ，図-1 から図一2への変化はその一例で ある。これらの新しい区画は，その後さらに細かく分割 されるが，その分割の仕方は国や市などの上から決めら れるものではなく，居住者によって比較的自由に細分化 されたと考えられる ${ }^{15 !}$ 。

5）魚介類の売買に従事する者が多いのは, 魚市場が震 災後に築地に移転し，その関係の職業に就くものが多 かったことによると考えられる。これらの中には，居住

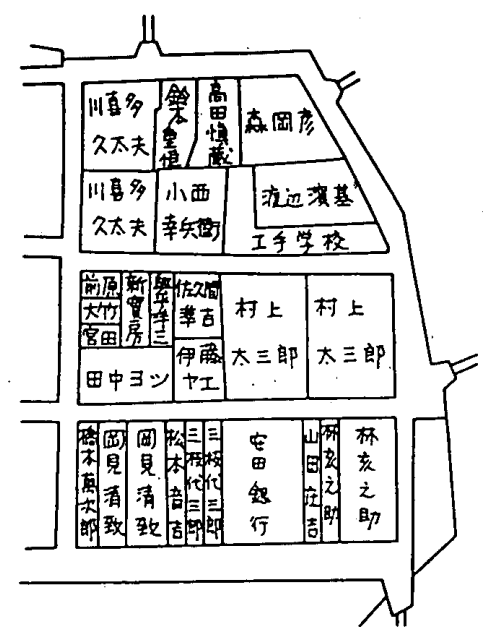

図一1 南小田原町付近（現筑地 7 丁目）地籍図, 大正元年

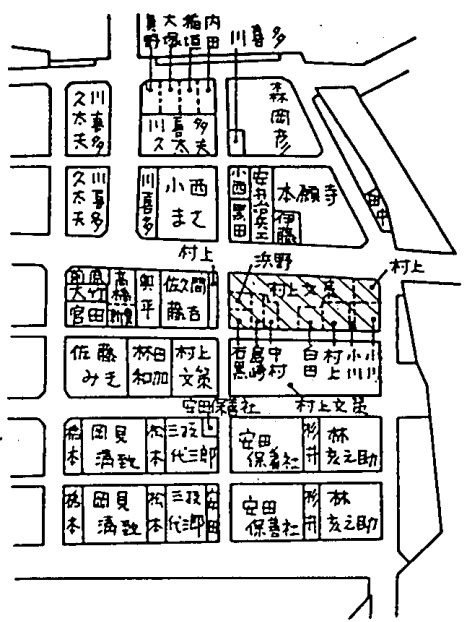

図一2＼cjkstart昭和初年の小田原町付近の地籍の変遷

（実線は区画整理時の地籍，破線は昭和 7 年までに新設 されたもの)

地において魚介類の問屋を営む者もおり，これらの家は 表土間をもつ店舗併用の住居になっている。

以上に調查住居の特色について簡単に説明をした

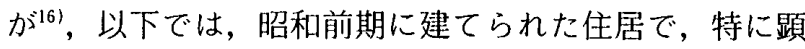
著であった変化や，その特徵について詳しい考察を行い たい。

\section{IV. 木造 2 ・ 3 階建住居の増加について}

佃島では，明治中期頃から 2 階の面積の増加の傾向が 顕著であったが，今回の調查住居には 3 階建の住居が比 較的多く見られる (表一1参照)。当時の統計をみると， 大正期から昭和前期にかけて，次のように $2 \cdot 3$ 階建住 居が増加していることが分かる。

表一2 は統計 ${ }^{17}$ に見られる，東京市及び各区における 大正 5 年から昭和 10 年までの木造住居の階数別棟数の 変化をグラフ化したものである。

まず，平屋から $2 \cdot 3$ 階建への変換期はいつごろであ るかについては, 各区においてその時期は異なるものの, 

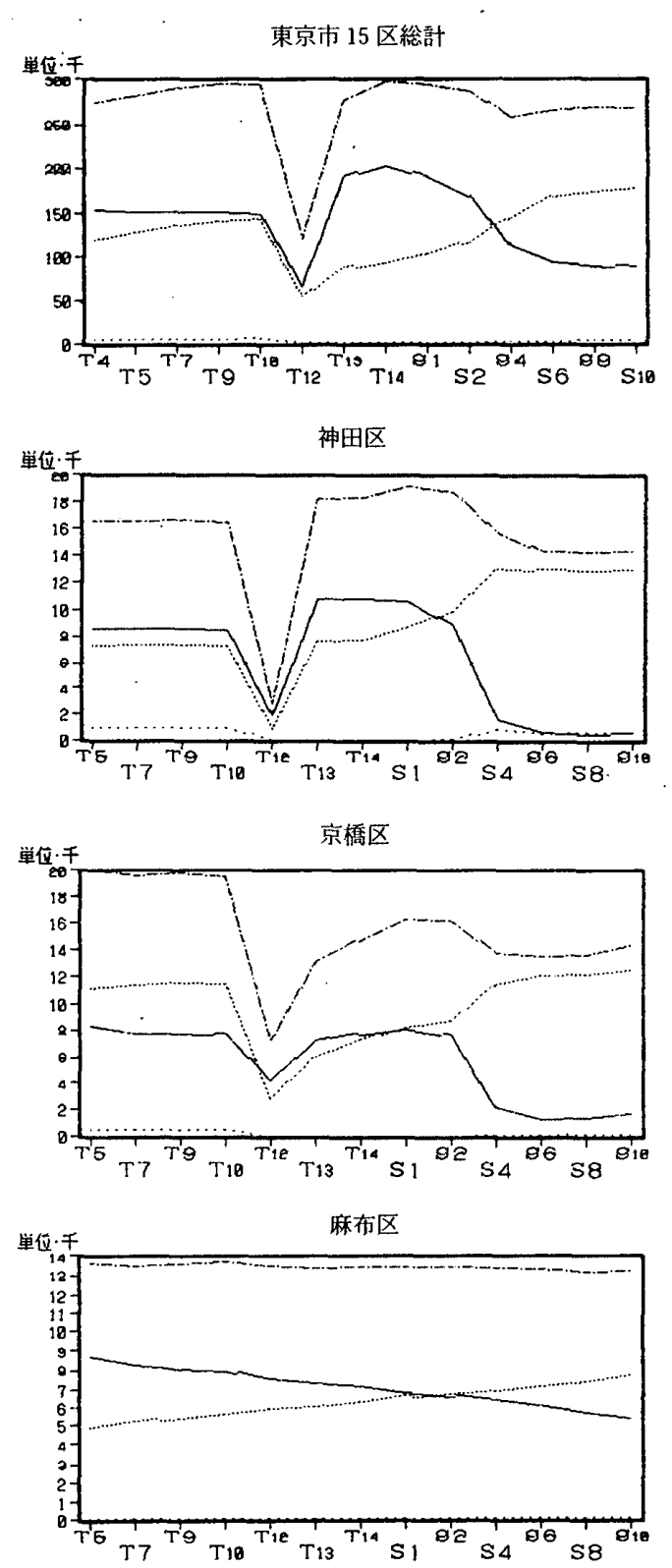

一応次のように考えられる。

東京市全体では，震災前は平屋が 2 階建より多く, 2 階建が平屋より多くなるのは, 昭和 2 年と 4 年の間であ る。その後, 昭和 8 年以降は 2 階建棟数が平屋棟数のほ ぼ倍になり，極端な差が晃られる。従って，東京市にお いては 2 階建が主流になる傾向は, 昭和 3 年頃に始まり， 昭和 8 年にはその傾向が固定する時期に入ったといえよ う。

各区については，震災前に既に 2 階建棟数が平屋棟数 を超えている区は，日本橋・京橋・下谷・本所・本郷区 の 5 区であるが, 残りの 10 区では 2 階建梀数は平屋棟 数を超えていない。従って，区によっては大正 5 年以前 に 2 階建棟数が平屋棟数を超え，2 階建が主流になって いるが，2 階建が平屋棟数より極端に多いのは日本橋・ 本所区でまだその区の数は少ない。多くの区では二者の 棟数が逆転するのは昭和 2 年から昭和 4 年にかけてであ
表一2 東京市および 15 区の各階別木造住居棟数婊
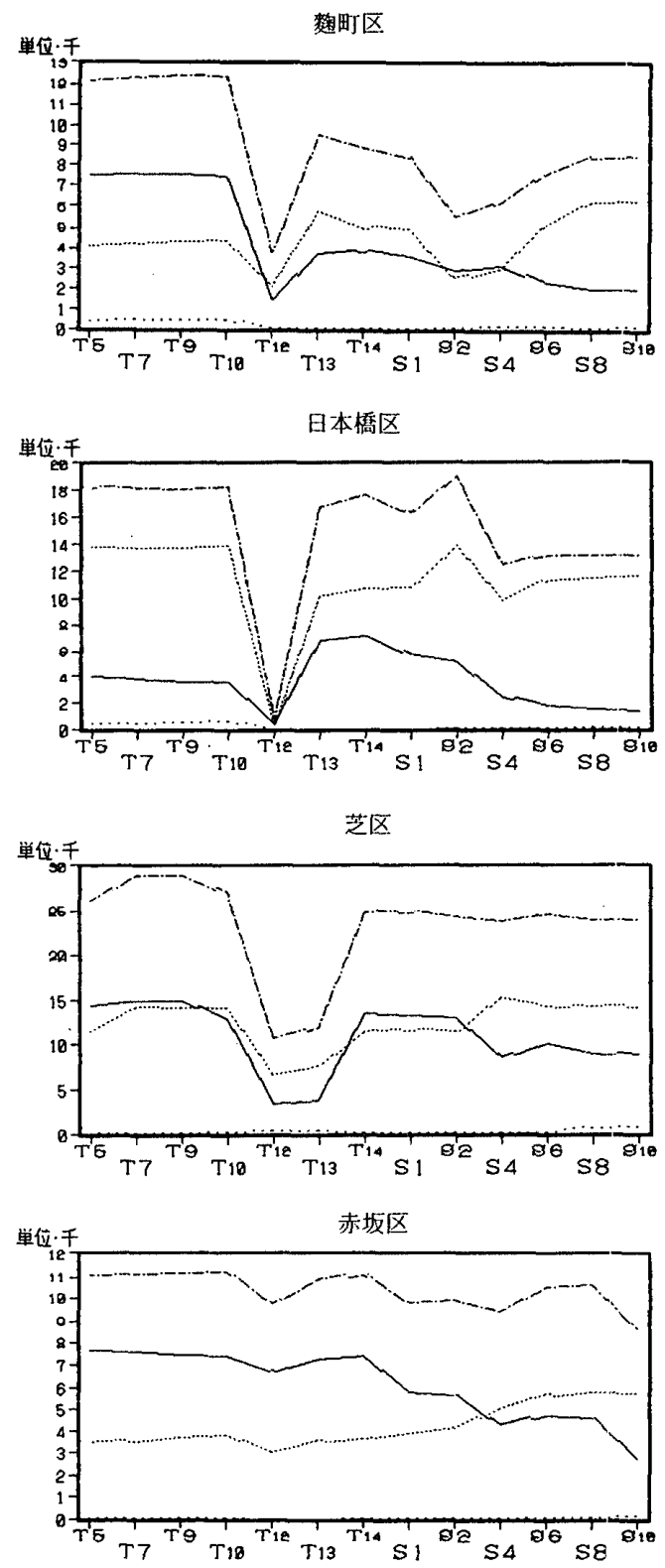

る。15区の外側部分に位置する牛込・小石川・本所で は昭和 10 年になって，ようやく平屋と 2 階建棟数が同 数になる。

3 階建については徐々にその数を増加させているが, 当時はまだ数が少なかったと言える。

次に, よ゙のような地域から階数の増加が顕著になって 来たのかについては，次のように考えられる。

$2 \cdot 3$ 階建が震災前にいち早く増加した区において, その人口密度及び戸数密度（戸数／宅地面積）を調べる と, それらの変化には，一応の対応関係がみられる ${ }^{181}$ 。 つまり, 震災前に 2 階建が全体棟数の半数以上を超えて いる区は先に挙げた 5 区である。また, 震災前に 3 階建 が 1000 棟を超えている区は神田・浅草区の 2 区であ る。これらの合計 7 区について震災前の人口密度及び戸 数密度を調べると，本郷区を除いて，いずれも他区と比 較して高い值を示している。従って，一定地区内に人口 

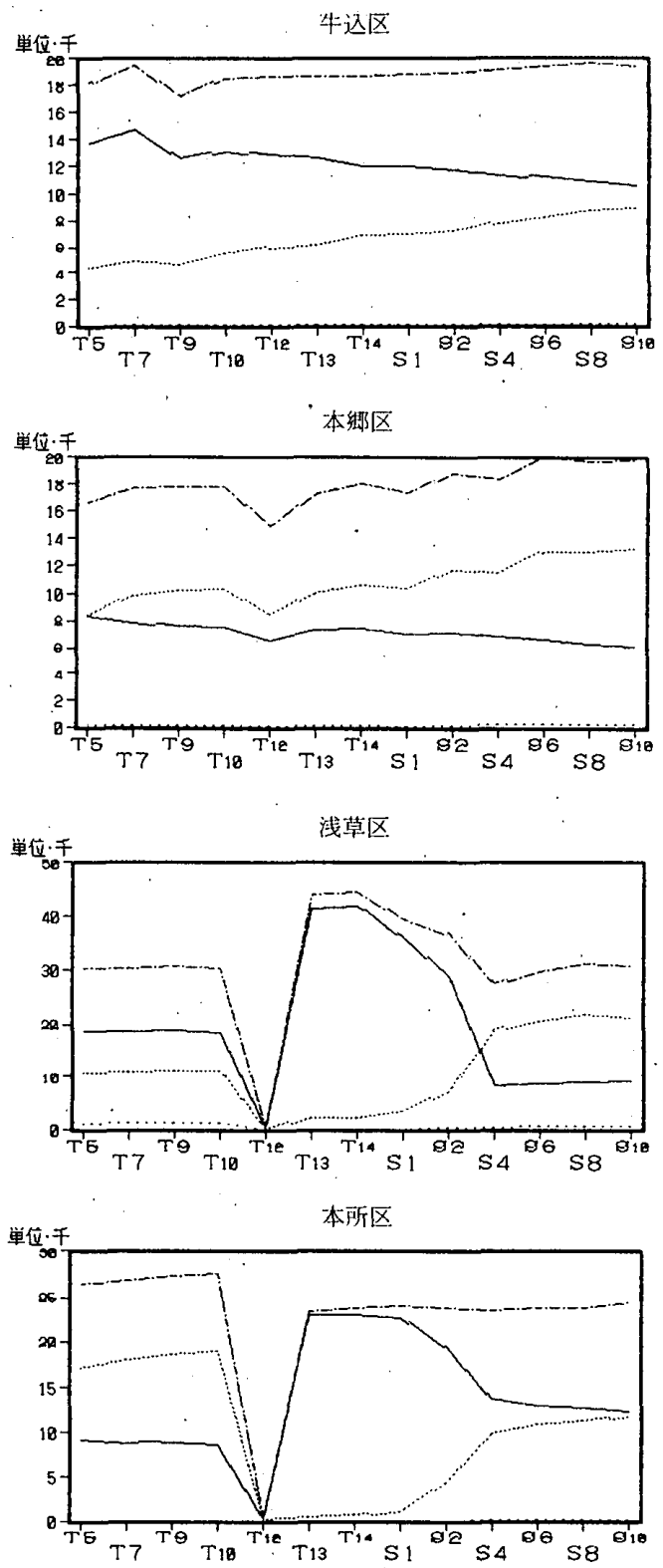

及び戸数が多い区ほゼ，上り早く2・3 階建化が始まっ ていたと考えられる。

\section{そのほかグラフから次のようなことが分かる。}

東京市の西側の震災で被災しなかった小石川・牛込・ 四谷・赤坂・麻布区においては，震災の影響はほとんど みられない。これらの非被災地区においては平屋は常に 少しずつ娍少し 2 階建は徐々に増加している。

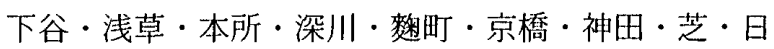
本橋区の 9 区は震災によって木造住居棟数を半数以下に 娍らし，特に，日本橋・浅草・樑川・本所区はほとんど 壇滅的な状況であったことが分かる。ところが，これら の 9 区では, その後, 平屋または 2 階建の棟数の急速な 回復がみられる。特に東京市の外側部分に位置する区(深 川・本所・浅草・神田・芝) では，2階建のなだらかな 增加に比較して, 震災直後に平屋棟数のきわめて著しい 増加がみられる。その後, これらの平屋は大正 14 年か
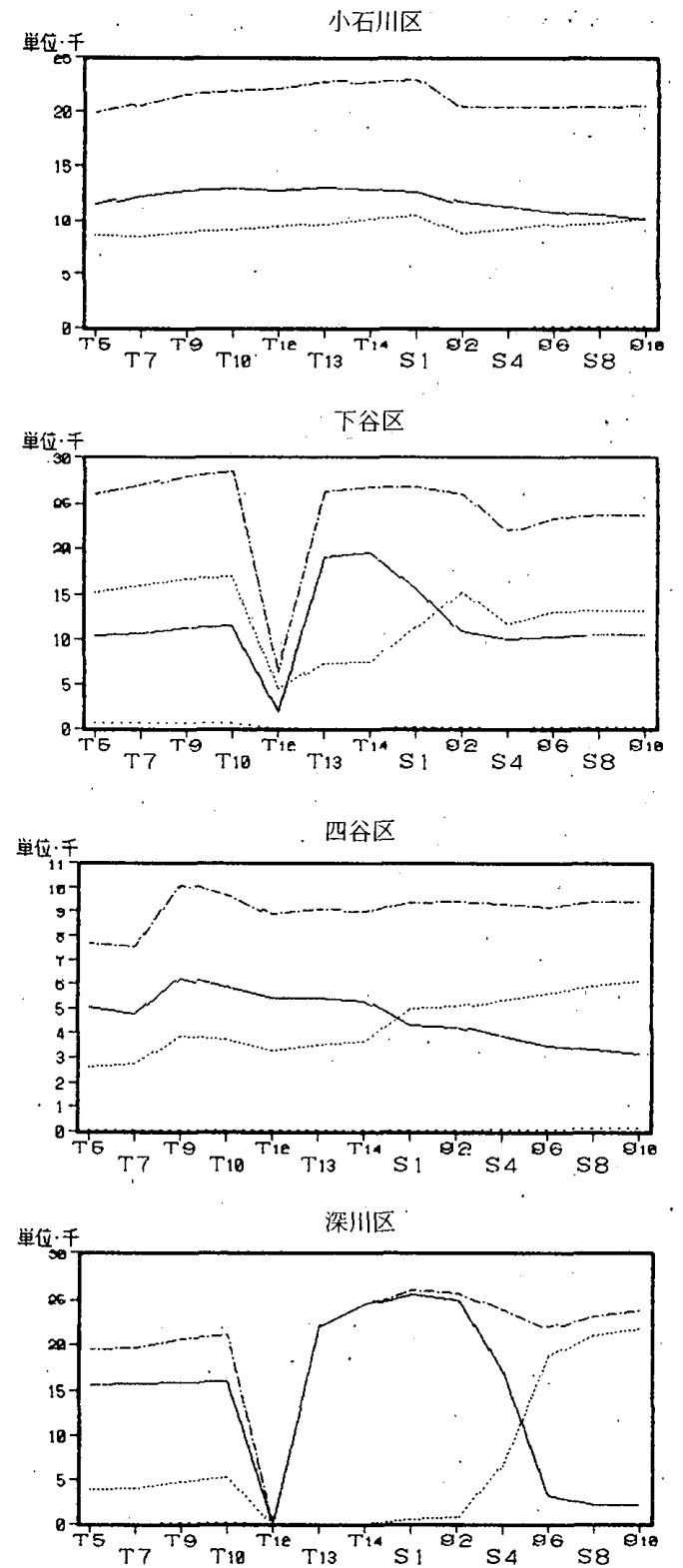

ら昭和 4 年までは放物線状に徐々にその率を高めながら 数を減少させ，その後は落ち着いた状況になる。この変 化は東京市全体の数にも影響を及ぼし，ほぼ同じような 変化をみせている。

また，震災直後に平屋の著しい増加のみられるこれら の区で平屋の建築面積を調べてみると, その数值は前後

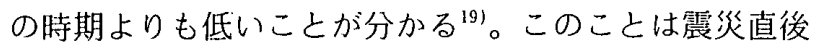
に建てられた平屋がその前後の住居よりも小規模であっ． たことを意味する。

これらのことから, 震災で家屋を焼失した家は, 緊急 に家屋を再建する必要があり，多くの家では経済的理由 等により本格的な家を建てることができず，以前より小 規模な平屋を建設しなければならない状況にあったと考 えられる。

また，先の平屋棟数が徐々に速度を速めて減少するの とは逆に，多くの区ではほぼ反比例するように，2 階棟 
数が増加している。この点は緊急に建設した平屋を徐々 に 2 階建等の本建築へ建て替えなければならない状況が あったことを推測させる。

さで, 上記の状況を間接的に作り出したのは, 大正 12 年 9 月の震災直後に制定された,いわゆる「バラック」 令 ${ }^{20)}$ と呼ばれた法令であったと考えられる。すなわち， この法令では建築線, 建築物の高さ，防火地区，美観地 区等に関する規定を免除されており，その建築着手の期 限は当初大正 13 年 8 月までとされていた。この着手期 限は後に延期され，この期限の設定が仮設住居の緊急な 建設を招いたと考えられる。この法令に依って造られた 「バラック」の数は, 震災後 3 年間に, 土地区画整理施 行地区内で 21 万棟に及んでいたと言われている211。従っ て, 先の小規模平屋は主にこの緊急に建設された仮設住 居を意味すると考えられる。

これらの仮設住居は, 当初の「バラック」令によれば, 昭和 3 年までに除去をし, 当時の建築法（「市街地建築 物法」）に沿った本建築に建て替えなければならなかっ た。しかし，除去の期限は昭和 2 年に昭和 13 年 8 月ま で延期されることになった。昭和 $2 \cdot 3$ 年頃に急速に 2 階棟数が増加するのは, この延期の発令される以前に建 て替えの計画が既に進行していた家によるものと推測さ れる。これらの 2 階建住居は，ほぼ同じ時期に建設され たと推定される多くの調查住居の水準からみて，かなり の住居水準に達したものか湕てられたと考えられる。

また，3階建が多い地区をみると，早くから 2 階化傾 向が強い東京の中心街（日本橋・京橋）が多いとも考え られるが，神田・浅草も多く，全体では現在の下町と呼 ばれる旧市街地，すなわち早くから市街地化が進んでい た地区に 3 階建が多く造られていたと考えられる。

3 階建の住居は, 震災前の東京でも計 5000 棟近く建 てられていたが，震災でそのほとんどを焼失した。震災 後はそれまでより早いペースで增加し，昭和 10 年には 3000 棟以上の 3 階建の住居が建てられている。これら の 3 階建は専用住居にも採用されたと考えられるが, 調 查住居に見られるように ${ }^{22)}$ ，町家の住居に採用された例 が多かったと考えられる。当時の記録を調べると次のこ とが分かる。

表一3 は当時の警視庁の統計 ${ }^{23)}$ から，木造の「住居向
建築物」と「商業向建築物」の棟数を階数別に分けて表 したものである。「住宅向建築物」とは専用住居を意味し， 「商業向建築物」とは町家を主に意味したと考えられる。 二者の各階別の棟数を比較すると, $1 \cdot 2$ 階建は住宅向 建築物のほうが多いが，3 階建は商業向建築物の方が多 い。また，各建築物別棟数では住居向建築物は 1 階建の 占める割合が多く, 商業向建築物は $2 \cdot 3$ 階建の割合が 多い。従って, 全体では平屋の専用住居が多く建てられ， 町家では $2 \cdot 3$ 階建之なる場合が多かったと考えられる。

\section{2 階建住居の間取りについて}

次に，上記のように多数建設された 2 階建の町家が ど のような間取をもっていたのかについて考察したい。

佃島の住居について報告した中で，2 階の客座敖化之 2 階に連続した部屋が取られるようになったことを明ら かにした24)。調查住居にも同じ特徵がみられ，休面積の 大小に関係がなく，連続した部屋が 2 階にみら机る家が 多い。これらの部屋はほとんどが二間続きで，その一方 には床の間・違い棚が付属し，それぞれ客間・次の間と 呼ばれている。これまでの既存の研究で特に「続き間座 敷」と呼ばれ，周囲を庭で囲まれた専用住居に兒られる ことが明らかにされている25)。しかし，調查住居では町 家に続き間座敷の形式をもった住居が多く見られるの汃 注目される(町家 16 棟中 15 棟)。

調査住居の続き間座敷は次のような形式をもっている と考えられる。まず，二つの部屋の動線を考えると，廊 下によって客間と次の間の両方へ直接行けるようにした 形式（図一3・4参照）之，次の間を通って奥の客間へ 行くようにした形式とがある(図一5・6・7・8参照)。 また，間取の上からは続き間座敷になっていないが，畳 廊下を介して必要に応じて続き間座敷にできるょうにし た家がある(住居(1))。

これらの続き間座敷は寄り合いや人寄せに使えるよう にと設けたもので，昭和 20 年頃までは結婚式に使った 家もあった。また， 2 階の二部屋を人寄せのために使い 易いように，新築当初から家具の置き場所を板の間とし て，矩形の部屋が家具によって凸凹にならないように計 画した家もあった (月島地区の家)。また，聞き取りに よれば，次の間は普段の生活にも使ったが，林の間の付

表一3 東京市新築木造棟数表

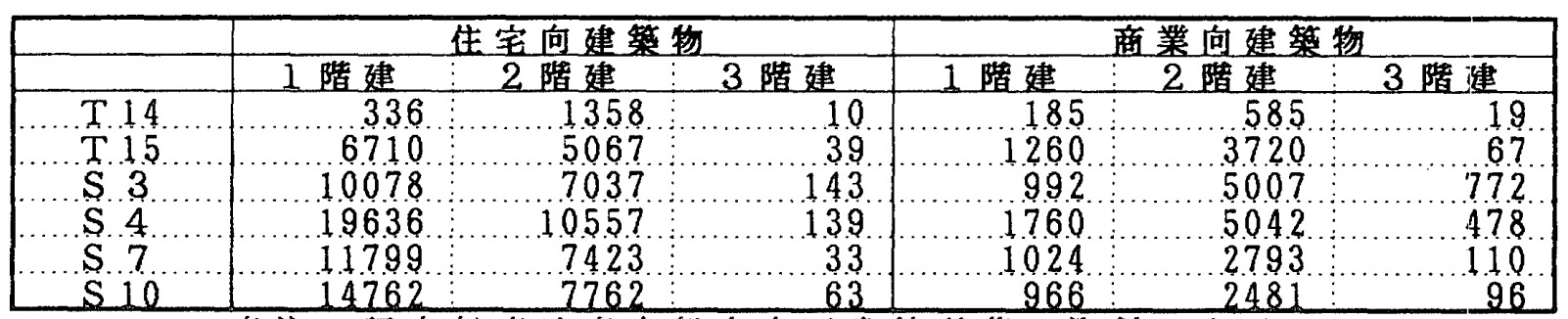

表注：調査年度は東京都中央図書館所蔵の䓄料による 

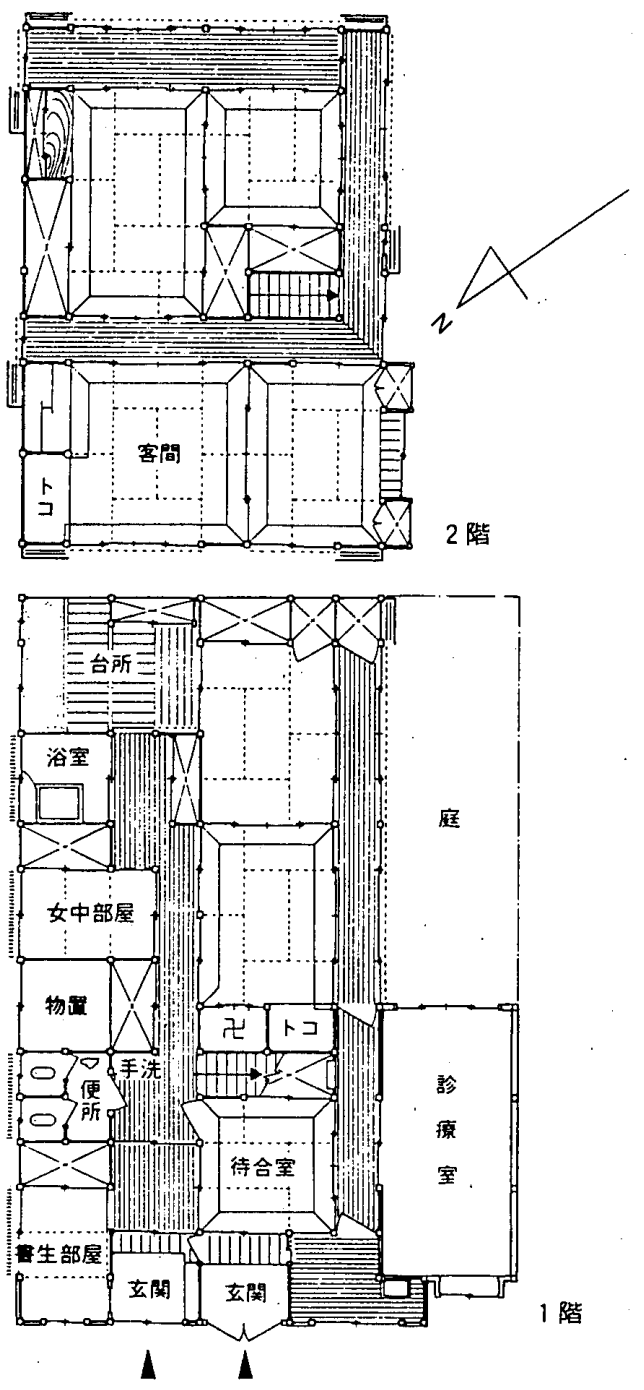

図一3 住居(5)復元平面図

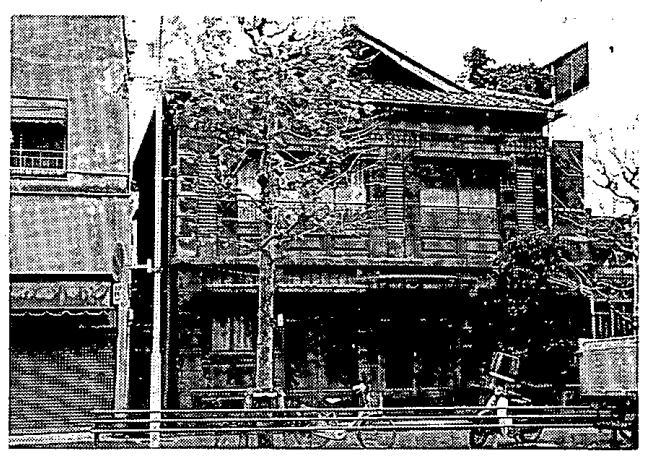

図一4 住居(5)写真（現状正面）
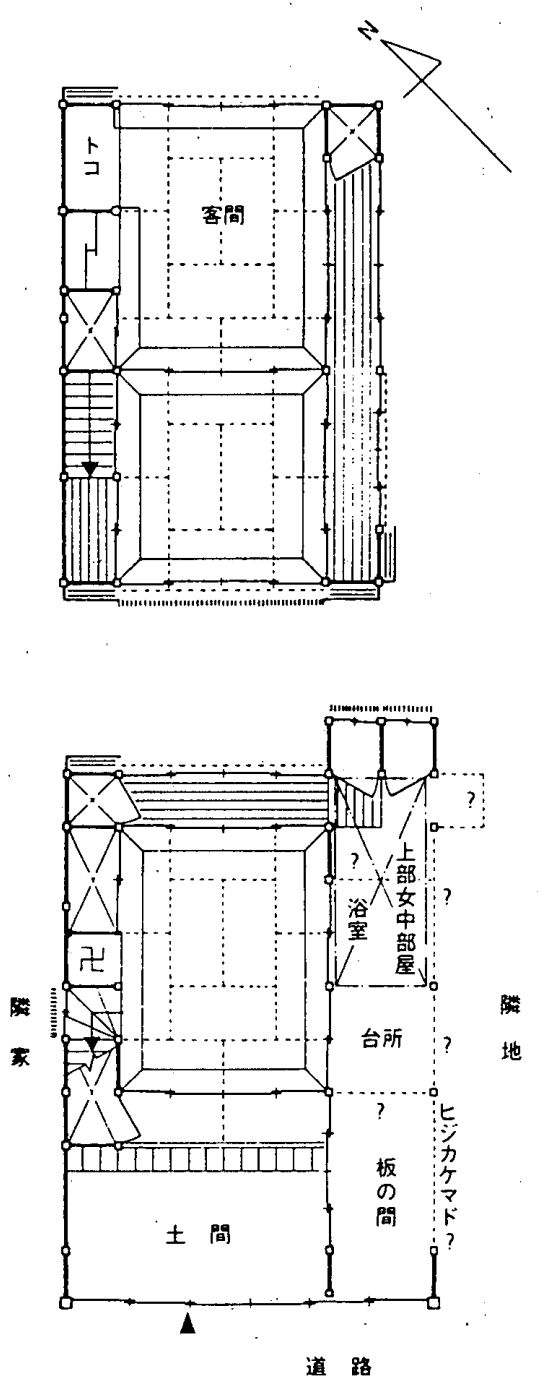

图一5 住居四復元平面図

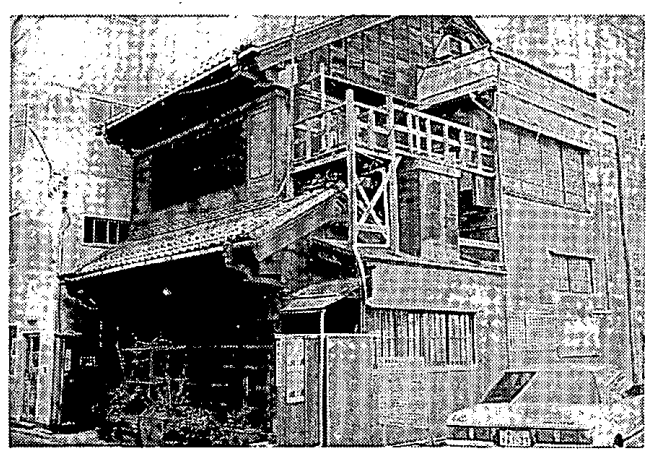

图一6 住居(12写真（現状正面）

いた部屋は客間用だけに使い，普段子供が出入りするこ とを禁じた住居もあった（住居(12)）。

以上のように，各家によって多少使い方は異なるが， ほとんどの家で連続した 2 部屋を，接客を基本として， 活用しようとしていたことが分かる ${ }^{26)}$ 。つまり，佃島で は明治中期頃に見られるようになったと考えられる 2 階 の客坐敷及び続き間坐敷の形式は, 調査地域の全体で昭 和の前期には一般的になっていたと考えられる。

また, 先の考察で, 東京市全体で住居の 2 階建化の傾 向が昭和の前期に強まったことについて明らかにした。 多くの調查住居の建築年代もこの時期に当たっている。 従って, 調査住居のもつ住居形式は, 2 階建化の著しく なりつつあったこの時期の東京市の住居の数少ない例証 であると考えられ，市全体においても，2 階の続き間座 敷の形式が一般化していた可能性を示していると考えら れる。 


\section{3 階建住居の間取について}

3 階建の住居は, 先のグラフにみられたように東京市 全体の家屋数では少ないが, 町家に多くみられ, 調査住 居にも比較的多くみられた。以下にはその間取について 検討したい。

調査住居に見られる 3 階建住居は 7 棟あり, その間取 は，1 階に多くは店に使う表土間を置き（7 棟中 5 棟），

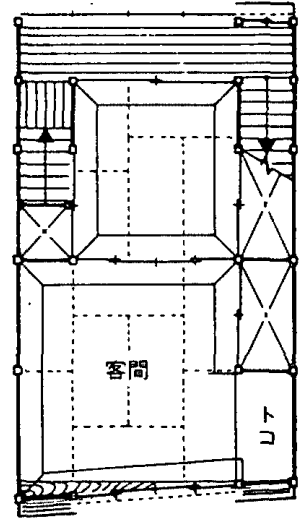

2 跸

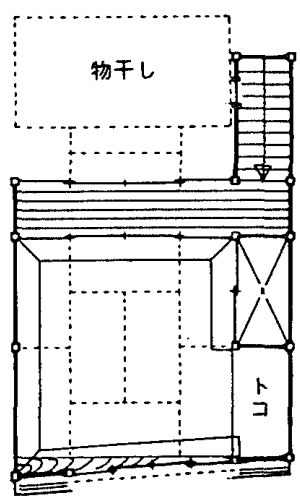

3 階
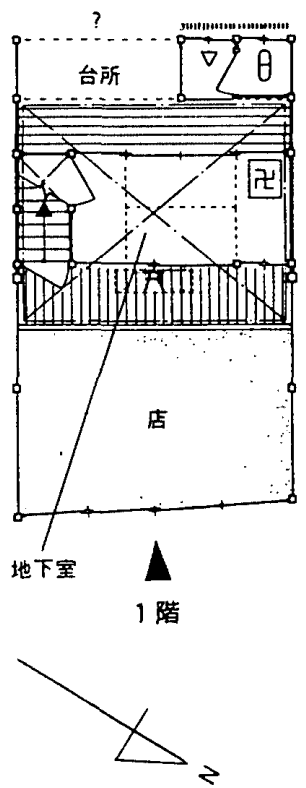

図一7 住居18復元平面図

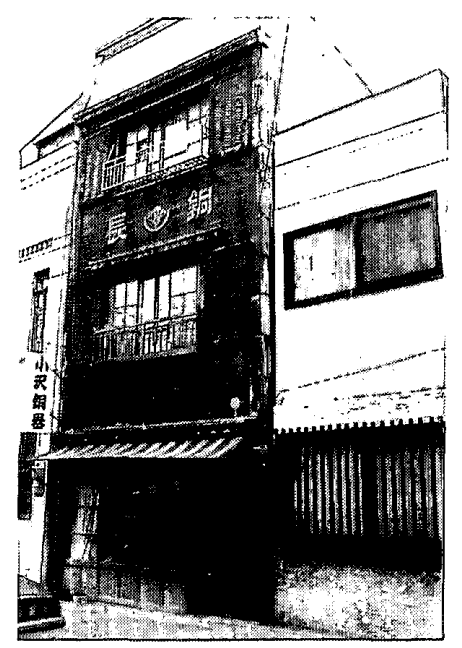

図一8 住居18写真 (現状正面)

茶の間・台所・便所をその後部に置いている。2 階は,

7 棟全てが床の間・違い棚を付属させた客間をとり，ま た，ほとんどの家が続き間座敷を設けている（7 棟中 6 棟)。2 階に便所を置く住居も 3 棟ある。3 階は, 多くが 一部屋で (7 棟中 5 棟)，床の間を付属させて主人の居 室としているものも 1 棟ある (図一7参照)。

3 階部分を，登り梁を使って小屋内に造っている住居 が 7 棟中 3 棟あり, 天井を張る場合も天井は低く，長押 を回さないなど，部屋の造作は 2 階の客間と比較してそ

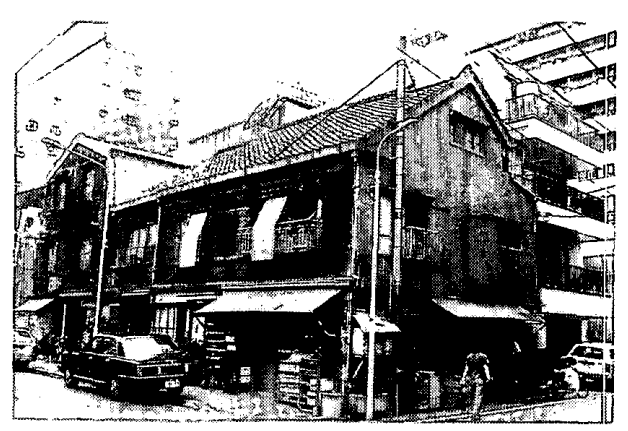

図一9 住居(1)写真（現状正面）

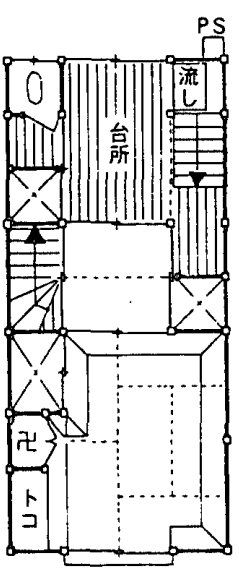

2 階
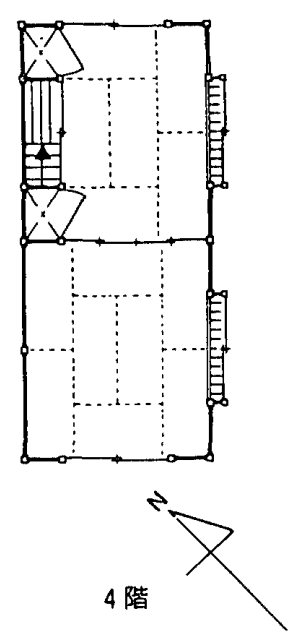

図一10 住居(4)復元平面図

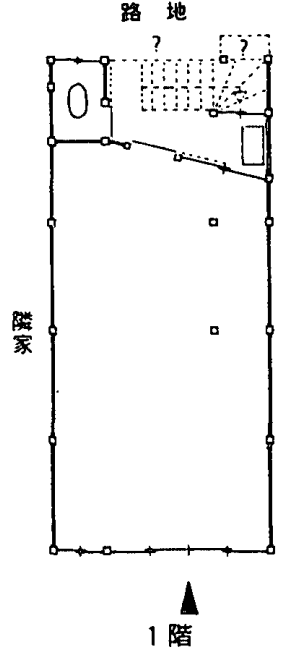




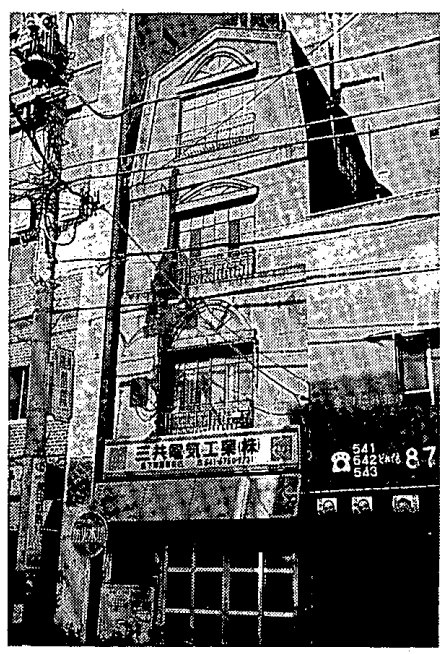

図-11 住居(4)写真 (現状正面)

の住居設備の水準は低いといえる。3 階部分は子供の部 屋とする場合と, 当時多くは通いであった使用人の部屋 とする場合があった ${ }^{27) 。 ~}$

3 階部分を, 登り梁を使って小屋内に造っている町家 の場合, 正面加ら 2 階建に見える(図一 9 右手前の棟)。 また，今回は調查ができなかったが，調查地区には 3 階 部分をマンサード屋根（腰折れ屋根）にしている町家も 何棟か見られた（図一9の左奥の棟）。

以上のように； 3 階建の場合，大正期まではあまりみ られなかった便所を 2 階に置く例が比較的多いなど, 新 しい形式もみられるが, 基本的な $1 \cdot 2$ 階の間取（各室 の配置）は 2 階建住居の間取とほぼ同じであり，新たな 変化はみられない。従って, 3 階建の場合, それまでの 2 階建住居の間取に，家族用の居室に使う部屋を 3 階に 付け加えた間取であると考えることができる。

4 階建は調查住居に 1 棟 ${ }^{28)}$ しかないが，その間取も参 考として簡単に説明しておきたい（図一 $10 \cdot 11$ 参照）。 1 階は店用の表土間（コンクリート床）があり，奥に便 所と洗い場を置いている。2 階は前方に床の間をもった 主人の居室を置き，この居室には仏壇が置かれている。 後方には台所が置かれている。台所横には大便所を付け ている。3 階は前方に床の間・違い棚をもった客間を置 き, 後方階段踊り場には小便所を付けている。4 階は又 ンサード屋根の小屋内に造られ, 家族の居室としている。

階数の増加傾向はその地域の戸数密度と関係のあるこ とについては前に指摘したが, これらの 3 階建以上の住 居の増加は, 市街地内の敷地面積の縮小化の進んでいた, 当時の町家の都市的立地条件によるものと推測される。 しかし，4階建の住居はほとんよ゙見られず，上記に説明 したように 3 階以上の部分については，その形式・構造 なよ゙から考えて、いまだ一つの定まった住居形式となり 得てなかったと考えられる。

\section{VII. 町家の建設における市街地建築物法等の影響}

（1） 3 階建住居の建設における市街地建築物法の影響 先にふれたように, 3 階建の住居は 2 階建の小屋内に 3 階部分を造ったり，2 階屋根をマンサード屋根にして， その小屋内に部屋を設けたものが多い。これは当時の「市 街地建築物法」(以後「市建法」と呼ぶ) と関連がある と考えられる。

市建法は大正 9 年に施行（同 8 年に制定）され，震災 後の大正 13 年に改正され（以後この改正法を「13 年改 正市建法」之呼ぶ）， その後昭和 25 年に「建築基準法」 ができるまで, 東京の建築物について規制を行ってきた。

市建法の施行は, 都道府県知事による建築許可という かたちをとるのではなく, 具体的な制限の内容を総て警 視庁の命令に委任していた299。住居の建設についても， 警視庁に位置図・配置図等の各図面を含む建築届を提出 することが義務付けられていだ30)。

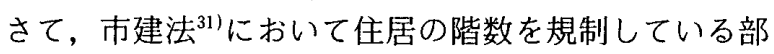
分（市建法施行令第五條）には

「(中略）木造建築物八高五十尺軒高三十八尺階数三尹， （中略）超過スルコトヨ得ス」「(中略) 木造二八土蔵造 尹包含ス」とあり, 木造住居の高さは土蔵造を含めて 50 尺（約 $15 \mathrm{~m} 15 \mathrm{~cm}$ ), 軒高は 38 尺(約 $11 \mathrm{~m} 51 \mathrm{~cm}$ ), 階数は 3 階を超えて建ててはならないと規定している。 その後の 13 年改正市建法によって, 建物高さは「四十 二尺」に，軒高は「三十尺」に改正され；この高さでは 実質的に 3 階建は建てられないので「階数三」までとい う規制は除かれている。従って, 大正 9 年からは木造住 居は 3 階までしか建てられず, 同 13 年以後は 2 階建の 住居しか造れないことになっだ22。

しかし，この階数の規定には「階数二八屋階及地階 包含七ス ${ }^{33)}$ とあり, 改正法には「階数卜八地階及屋階 ヨ除キタル階数习謂フ」という但し書がある。いわゆる 屋根裏部屋にすれば事実上は大正 13 年までは 4 階に, その後は 3 階に部屋を造ることが可能であった。先に説 明をした 3 階部分を登り梁を使って小屋内に造ったり， マンサード屋根にするなどの住居は，この但し書を利用 して，3階部分を法規上の階数に含めぬ上うにした庶民 の苦肉の策であったと考えられる。

先の統計の分析および実測調査の結果から，小屋内を 利用する形式でない純粋な木造 3 階建住居が昭和期に 入ってからも建てられていることが分かる。しかし，大 正 13 年からは木造の 3 階建住居は違法であったから, その数がざのようにして計上されたかは不明である ${ }^{33 ! 。}$ 東京の中心街である䴶町や日本橋・京橋は神田・浅草に くらべて震災前よりも 3 階住居の数が增加してない。中 心街の方か警視庁の監督が比較的行き届いていたと思わ れ，違法建築の規制になんらかの地域差が生じていた結 果であるとも推測される。しかし，いずれにしても事実 
関係が不明なので推測の域を出ない ${ }^{351}$ 。

（2）正面の構造形式に対する市街地建築物法の影響 当時の建築法規を分析すると, 正面をフラットにした 町家が多く建てられるようになったことも，以下のよう に市建法の影響が考えられる。

市建法では「建築線」尚が次のように定められている。 「道路敷地ノ境界線 築物ノ敷地八建築線二接セシムルコト尹要ス（中略）」(第八 條）「建築物八建築線ヨリ突出七シムルコト 線力道路幅/境界ヨリ後退シテ指定セラレタルモノナルトキ 八命令ノ定ムル所二依り建築物/前面突出部又八基礎八道路 幅ノ境界線习越エサル範囲内二於テ建築線ヨリ之ヨ突出セシ ムルコトヨ得」(第九條)

また，市建法第二十六條に「本法二於テ道路ト称スル八幅 員九尺以上ノモノヨ謂フ」とある。

以上の内容から考えて, 町家のように道路に面した住 居は，敷地を幅員九尺以上の道路に接していなければな らず，道路境界を以て建築線とし，建築物は基本的には その建築線より突出して建築することはできなかった。 但し, 建築線が道路境界よりも後退して指定されている 場合は, 前面突出部分または基礎に限り命令の定めると ころに従い突出することができた。

そして, この命令は市建法施行規則第四條・五條に よって次のように定められていた。すなわち, 前面突出 部分は蛇腹・軒・小塔・出空などこれに類するものは, 路面上 10 尺以上にある場合は 3 尺まで, 出入口の階段 や庭の囲い等は 1 尺まで, 基礎は道路境界線を超えない 範囲において, 建築線より突出してもよいと定められて いた。従って, 路面上 10 尺以上となる 2 階の軒は前面 に突き出すことができるが，1階の軒または庇は, 普通 はその高さが 10 尺以下になるので, 前面に突き出すこ とができないことになる(図一12,13参照)。そして， 後の 13 年改正市建法によって「路面上 10 尺」は実情に

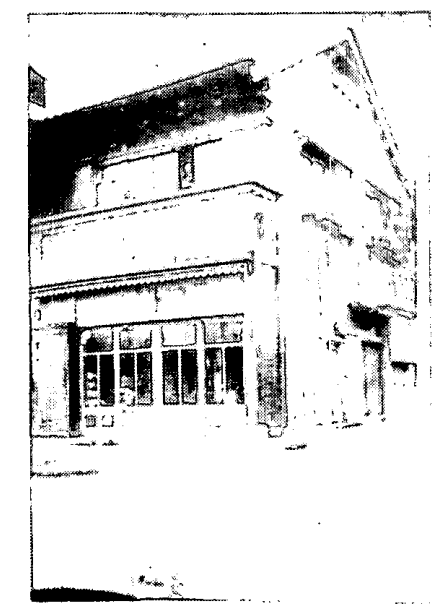

图一12 住居(15)写真 (建築当初正面)

1 階正面をフラットにして銅板張りとして壁面から軒 等を出さない構造としているが, 2 階正面は出析造と なっている。
合わないということで「8尺」に変更され，1 階の軒 · 庇も高さによっては突出できることになった。

さて, いずれにしても, 前面突出部分は建築線が道路 境界より後退して指定された場合で，一般的には道路境 界を以て建築線としたから，道路境界線を超えて建築物 を建築することはできない。従って，明治期まで東京の 町家の最も一般的な構造であったと考えられる出桁造 は, 前面に軒が突出する構造的特徵から, 前壁面を軒の 分だけ後退して建てなければならず，敷地を有勃に利用 する上で不利となる。また，先に記したように，当時 2 階には面積の拉大傾向があり，2 階正面を 1 階の正面よ り後退させた構造より，フラットにした構造の方が，2 階面積を多く確保できる。従って, 効率の良い構造は正 面がフラットで凹凸が無いものがよいということにな る。

さらに，この建築線については市建法第十條に「行政 官庁八市街ノ体裁上必要卜認ムルトキハ建築線二面シテ 建築スル建築物ノ壁面ノ位置习指定スルコトヨ得」とあ り，出桁造の家を建てる場合のように，逆に道路境界か ら後退して建てる建築をも考えて, 強制的に建築物の壁 面が凹凸無く揃えられる条項をもうけている。この指定 がどの程度実行されたのかは不明であるが，上記の条項 の存在を考えると，行政側にはかなり積極的に壁面線を 揃えようとした都市計画上の意向があったと将えられ る。そして，「体裁上」という言葉から想像されるように， 視覚的な意味で, 複数の町家の正面が軒等を出さずにフ ラットに揃うような構造が好ましいとする考え方が, 当 時の行政側の意識にあったことは想像するに難くない。

（3）正面の銅板張り構造と仮設建築物法

調查住居で正面がフラットになっている壁面の被覆 に，多くは銅板が使われている。この点については以下 のように考えられる。

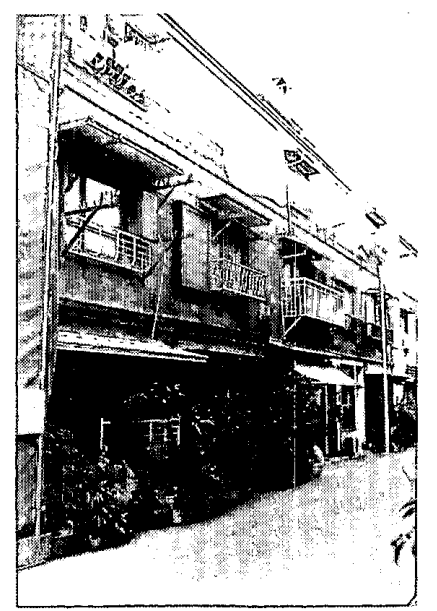

図一13 住居8)写真 (現状正面)

8 軒長屋で, 復元によると正面の庇や戸袋はすべて後 補で, 創建当初は壁面からの突出部分は全くなかった と考えられる。 


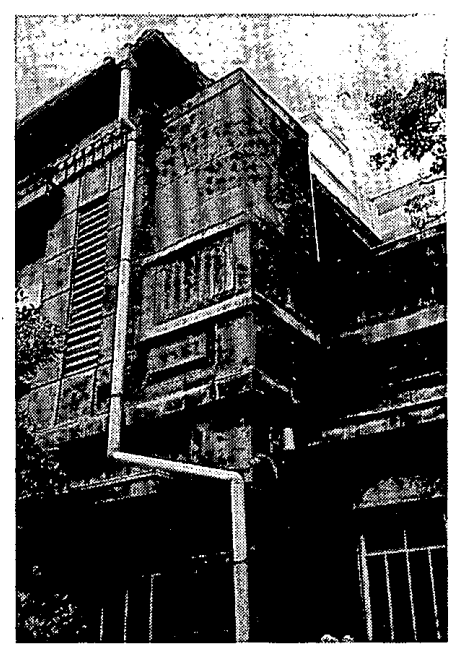

図一14 住居(5)写真（正面銅板部分）

まず, 銅板を使用した調查住居 7 棟のうち, 住居(5) (図 -14）は防火地区 (甲種) の指定区域内にあり，その他 の住居は指定区域外にある。防火地区外の 6 棟について は, 法的には外壁の被覆は必要ないが, 防火地区内の建 物については，市建法で外壁を耐火構造とすることが義 務付けられている37!。ところが，市建法では，外壁につ いて，銅板のような金属板による被覆を耐火性を有する 構造之は認めていないから ${ }^{38)}$, 防火地区内の銅板張りの 木造建築は基本的には違法となる。

しかし，先にふれたように，震災直後に仮設建築物法 が施行され, 震災被災区域においては仮設建築物の建設 が認められていた。この法律では一定期間内において, 市建法施行規則第 1 條（通則）は適用しないと定められ ていだ $。$ 。従って, 震災被災区域に建てる町家の場合, 外壁等の耐火構造の規制を免れていたことになる。そし て, 大正 13 年には警視庁令によってその構造が規定さ れるが, 当時の経済状況では一般庶民に完壁な耐火建築 を要求することは無理があるという考え方から, その規 定は 2 階建以下とし, 屋根を不燃材料で被覆しなければ ならないという極めて簡単な規制となっだ01。

仮設建築物の着工期限は当初の大正 13 年 8 月から, それぞれの地区において復興計画による移転命令がでる までに延長され，東京では地区によって大正 15 年から 昭和 5 年の間まで延長されることになった ついては昭和 2 年中に移転命令が発令されており ${ }^{42}$, 先 に記したように，他の震災被災地区でも昭和 3 年末には ほとんよ゙が移転工事を完了している。

従って, 被災地域においては, 防火地区の指定の有無 にかかわらず, 震災後から昭和の初めまでは外壁の耐火 性は法的には義務付けられていなかったことになる。

さて, 調查住居(5)では, 建築時（昭和 $3 \cdot 4$ 年）に大 工から, モルタル叙りにするか銅板張りにするかを選択 するようにいわれ，モルタル塗りは中の木材が蒸れる心 配があるという理由から, 最終的には銅板張りを選んだ
と伝えられている。このことは, 当時, モルタル塗が法 律的には耐火性を認められながらも, 未だ木造住居の外 壁の施工方法として広く一般には認められていなかった ことを示していると考えられる43!。

また，市建法施行規則第百二十八條には「種防火地 区内二在儿建物ノ軒, 軒蛇腹, 屋空装飾塔ノ類八不然材 料フ以テ構成シ又ハ被覆スヘシ」とあり，また延焼の恐 れのある開口部の部分について「金属板 シ以テ被覆セル モノ」は防火性があると認めている条項がある44)。

従って, 銅板張りの家屋が震災直後に建設されている ことから考えて, 当時モルタルによって木材を包むとい う工法が一般化していない状況下において，それまで屋 根等に施工されてきた従来の施工方法, すなわち金属板 を以て木材を被覆する方法が防火構造として多くの場合 採用されたと考えることは無理なことではない。

以上のような状況を考えると, 調査地域において銅板 張りの木造建築が比較的多く残されている理由は, 建て 主が火災による延焼を意識して, 自主的に防火手段の一 つとして銅板張りを採用した結果であると考えられ る45)。

仮設建築物は, その現状が市建法に適合している場合 は，その後も勅令によって無制限に除去を免除されだ66。 防火地区内の銅板張りの住居もこの勅令を準用すること によって，その除去を免れ，現在の東京に今日まで残さ れたと推測される47。

\section{VII. 結 語}

最後に, 以上の考察で明らかになった点をまとめ, 結 びとしたい。

a) 東京市における 2 階建住居の増加は, 市街化が早く 進んでいた区では，大正初期以前に既に顕著になってい た。しかし, 東京市全体で 2 階建が主流となるのは, 昭 和一析の時期であったと考えられる。3 階建住居は, 2 階建住居に比較してその数はきわめて少ない。

b) 昭和前期に建てられた 2 階建, 3 階建の町家は 2 階 に客座敷の形式をもっていて，ほとんどが続き間座敷の 形式を備えていた。従って, 東京の町家では, ほほ昭和 前期に 2 階の続き間座敷の形式が一般化していたと考え られる。

c） 3 階部分は家族のための部屋として使用されたが, その構造によって使い方が定まらず，未だ明確な住居形 式をもっていなかった。この 3 階部分の住居形式が未発 達であるのは，3階建を事実上禁止した市街地建築物法 (改正法) の影響であると考えられる。

d）震災以降, 正面をフラットにした町家が増加したが, これは市街地建築物法による建築線の指定という法的規 制の影響であり，特に震災復興時の区画整理によって壁 面の位置が整えられたためと考えられる。 
e）震災以降から昭和 10 年頃までに建てられた町家の 正面の材料は，銅板張りが比較的多く見られる。これは， 庶民が震災による火災経験を通して防火構造を意識し， 当時施工方法がよく知られていた銅板張りを自主的に採 用した結果であると推測される。特に，昭和 3 年頃まで の防火地区内においては，仮設建築物法による一時的な 法規制の緩和によって外壁の耐火構造が必要でなかった ため，銅板張りや耐火被覆のされていない木造住居が建 てられていた可能性がある。

\section{謝 辞}

調査にあたってお世話になった中央区教育委員会及び 各調查住居の居住者の方々に心よりお礼申し上げます。 また, 調查の機会を与えてくれた千葉大学工学部玉井哲 雄助教授，および本稿の作成にあたってご助言をいただ いた丸山純助手に感謝いたします。そして，本稿をまと めるに当たって数々の貴重なご助言をいただいた千葉大 学工学部大河直躬教授に深く感謝申し上げます。

注

1）拙稿「明治・大正期における佃島の住居の類型と変遷」(日 本建築学会論文報告集第 396 号, 1989 年 2 月)。

2）筆者のこれまでの京島地区・本郷地区・西方地区等の下 町における住居調查による。この点は筆者の修士論文に その一部を発表した。

3）この調查は中央区教育委員会の低頼によって, 千葉大学 建築学科玉井哲雄助教授（調查主任）を中心とする玉井 研究室のメンバーが行ったもので，筆者は調查副主任と して調查に参加した。具体的な調查内容は「中央区の文 化財 (建築編)」(中央区教育委員会・昭和 62 年) に発表 された。本論文への調查の成果の利用については, 中央 区教育委員会と玉井助教授の許諾を得ている。

4）別稿において調査した町家における片側廊下の形式の発 展について明らかにする予定である。

5)「帝都復興事業大観」(昭和 5 年 3 月 - 日本統計普及会) の「東京防火地区図」を参照。道路の両側 6 間分が防火 区域に指定された。旧日本橋・京橋区内の部分はすぺて 甲種防火地区に指定されている。

6）一次調査は中央区全域をフィールド調査し，できるだけ 多様な住居形式（出桁造・銅板張り等の外観に於ける意 匠の違いによって選択）を網羅した調査可能を建物を選 出した。二次調查は建物の現状図面（平面・断面）及び 復元平面図の作製, 建物内外の写真撮影, 住生活や職種 等についての聞き取り調查を行った。

7）前掲毒「帝都復興事業大観」の「東京土地区画整理進捗図」 による。この図には, 復興事業地区に於ける各地区の移 転発令時期や移転完了の時期が色分けされている。

8）東京市統計局「東京市統計表」の各年版による。

9）北澤五郎「復興東京の技術的観察並に建築の変遷」(都立 中央図書館所蔵「関東大霞災之帝都復興事業」内）所収 の「大正十二年震火災㜔失地区内各年竣功建筑物調」 64 頁の表による。ちなみに，木構造新築棟数は大正 12 年か ら昭和 5 年までの各年は, $7 \cdot 1279 \cdot 1214 \cdot 3373 \cdot 4765 \cdot$ $5910 \cdot 3823 \cdot 2915$ 棟となっている。
10）前揭注 5）文献の「建物移轉工事実施月別表」による。

11）この点については, 住居棟数の変化と関係があり, 更に 詳しい分析が必要と考えられるが，ここではこ沉以上細 かい分析はしないことにする。

12）現在，このような建物を「看板建築」という言㻡で表現 することが多く行われているが，筆者には「看板」とい う表現は，その構造・意匠をさすのに妥当とは洘えられ ないので本稿では使わなかった。藤森昭信「看板建築の 概念について」(日本建築学会昭和 50 年度大会学術講演 梗概集) 参照。

13）前揭注 1）論文。

14）江面嗣人，三浦卓也「昭和初期における東京都中央区の 木造住居について・その1」(日本建築学会昭和 62 年度 大会学術講演梗概集）に揭載した図による。区画整理に よって, 各敷地において道路に接する部分が多くなって いるのが分かる。

15）住居(7)では敷地を購入する時に，分譲業者から他の 3 人 の購入者と相談して敷地割を決めるように要求されたと いう。

16）これらの特徵については注 14）文献で報告した。

17）「東京市統計表」には，大正 5 年から昭和 10 年の間は, 木造で且つ住居である各階数別の棟数が記録されている が, 前後の時期は木造または住宅という分類でのみ棟数 が記録されているため, 木造住居の棟数は不明である。

18）人口密度については「東京市統計表」の明治 41 年の市勢 調查, 大正 9 年の国勢調查, 大正 12 年霞災地人口調査, 大正 13 年の市勢調查, 大正 14 年・昭和 5 年・昭和 10 年 の各年の国勢調查による記録を調查し，戸数密度に関し ては第 29 回「東京市統計表」の 143 頁に载っている大正 元年から昭和 7 年までの「世帯及增加割合」の世帯数空 それぞれの年の宅地面積で割った値を検討した。

19）前揭の「東京市統計表」によって, 東京市 15 区の大正 5 年・ 13 年, 昭和 4 年の平均建坪（総建築面積/総棟数） を比較した。ちなみに, 東京市全体では，大正 5 年・13 年・昭和 4 年のそれぞれの平屋の平均建坪は 19.68 坪・ 11.62 坪. 16.91 坪で, 2 階建の平均建坪は 15.37 坪. 17.96 坪・16. 47 坪である。2 階建の平均建坪がほとんを゙ 変化がないのに比べて, 平屋の大正 13 年の平均建坪は前 後の年代と比較して約半分近くになっており,極端に減 少している。

20）正しくは「東京府及神奈川縣ノ市街地建築物法適用区域 二於ケル仮設建築物等二関スル件」(大正十二年九月十五 日勅令四百十四号及び同年同月十七日内務省命第三十三 号)。

21）「帝都復興事業誌」復興事務局，昭和 6 年 3 月 31 日。

22）今回の調査では明石町 11 丁目 11 番地に 1 棟を確認した のみである。この住居については残念ながら実測調查妾 行うことができなかったが, 正面に玄関を構え, 周囲に は狭いながらも空間を空け一部に庭をもち，明らかに一般住居の形式をもっている。

23）「擎視庁統計書」(警視庁総監官房文書課) の大正 15 年加 ら昭和 11 年までの各刊の統計による。

24）前揭注 1）論文。1階の間取については，この論文の中で 詳しく検討したので,ここでは省略する。

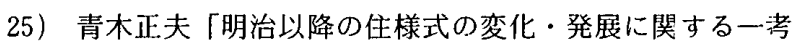
察」住宅建築研究所報・ $1985 \cdot$ No. 12 等を参照。

26）聞き取りによれば, 普段の生活の中で十分に活用されて 
いたとは言えないようである。

27）このような 3 階部分を小屋内に造る形式は, 当時の建築 法規とも関係するので後に詳しく分析する。

28この 4 階建については，建築当初 3 階建だったという聞 き取りがあり，その根拠は，家に残された建築図面が 3 階建であった，というものである。しかしながら，筆者 の㬰測によれば，4階部分を継ぎ足した痕跡は認められ なかった。

また，この 4 階建はほぼ昭和の一析代の建築と推定さ れ，4 階部分をマンサード屋根の小屋内に造っている。 詳しくは後に記すが，昭和期には 4 階建は違法であり，4 階部分を小屋内に造ったこの 4 階建は，当時，法的には 3 階建とみなされていたと考えられる。従って，4 階部 分は法律上の階数に含まれず，4階部分は建築図面から 意図的に省かれたと考えられる。筆者が調查した住居15 は小屋内に 3 階部分を造っているが，当時警視庁に提出 した建築届には 3 階部分は描加ていない。

さらにまた，当時の住宅地図を調べると，この4 階建 は戦後少なくとも 4 回居住者が変わっているのが分かる。

以上の理由により，先の 3 階建であったよいう証人は 建築当初の居住者ではなく, 後の居住者が建築届の図面 を見て,この 4 階建が建築当初は 3 階建であったと誤っ て判断したものと考えられる。

29）島田信次, 関 哲夫「建築基準法体系」酒井書占, 1985 年 8 月, $6 \cdot 7$ 頁。

30）内務省都第 147 号（大正 9 年 12 月 10 日）により，建築 位置図・配置図・平面図等を含む建築台帳を作ることが 警視庁に指示された。

31）「官報」（第二千四百四十九号，大正 9 年 9 月 30 日，印刷 局)による。

32）前揭書「帝都復興事業誌」p. 155 参照。

33）「屋階」については，市建法施行規則の第一條三項に「屋 階卜八屋根袈二設ケタル階习謂ウ」とある。

34）統計局がマンサード屋根の住居のように, 屋根亴に部屋 を造ったものも 3 階として計上したとも考えられるが, 当時一戸一戸を調査した訳ではないので，可能性として は薄い。

木造 4 階建の住居についても，市建法の内容から考え て, 大正 8 年から同 13 年までは屋根裏部屋とすれば不可 能ではなかった。しかし，その後は 4 階建ては総て違法 になり，法律的には建築が不可能であった。しかし，先 に説明をしたように，調查住居には 4 階建が 1 棟あり， この建物がどのようないきさつで建設されるようになっ
たのかは不明である。

35）当時の東京市の建築は警視庁の建築監督職員によって監 督されていたが，十分な人数がいなかったという記録が ある。前揭書「帝都復興事業誌」p. 169 参照。

36）建築線については石田頼房によってかなり詳しい研究が されている。石田頼房ほか 2 ,名「建築線制度に関する研 究・その $1,2 」$ 総合都市研究, 第 6 号 1979 年・第 10 号 1980 年等。

37）市建法施行規則第百十九條「甲種防火地区内二在ル建物 八其ノ外壁ヨ耐火構造卜為スヘシ」

38）市建法施行規則第百二十七條における準耐火構造の規定 でさえも，木造の被㠅材として暑さ 1 寸 2 分以上のセメ ント・モルタル・コンクリート塗を認めているだけで, 金属被覆は認めていない。

39）「東京府及神奈川縣ノ市街地建築物法適用区域二於ケル仮 設建築物等二関スル件」(大正十二年九月十五日勅令第四 百十四号) 参照

40）「市街地建築物法適用区域二於ケル仮設建築物等ノ構造設 備二関スル件」(大正十二年九月警視庁令第四二号) 参照

41）「大正十二年栜令第四百十四号第一項/規定二低儿建築着 手期限ノ延期二関スル件」(大正十三年八月二十二日栜令 第百九十八号)

42）前掲注 10）の表による。

43）筆者の調查によると，前面にモルタル塗が一般に広く使 われるようになるのは，昭和 10 年前後であったと推測さ れるが，この点については更に詳しい調査が必要である。

44）市建法施行規則第百二十九條に「隣地境界線又八隣接建 物ヨリ水平距離三間未満ノ位置二在ルトキ但シ悹ノ枠及 組子鉄造又八金属板 キ以テ被覆セルモノ八此/限二在ラ 不とある。このような条項は，木材部分を不然材料て 被覆することが，火災を免れる手段として有効であると いう考え方を示すには有用であったと思われる。

45）モルタル塗及びタイル貼りを採用した 4 棟の調查住居も すべて防火地区外にある。

46）「大正十二年栜令第四百十四号ノ除去期限二関スル件」(昭 和二年三月十九日勅令第三十三号)

47）仮設建築物はその後, 本建築認定の出願をすることによっ て，許可されればそのまま存続することができた。当時， 膨大な数の認定許可申請が警視庁に提出されていたとい う記録がある(前掲書「帝都復興事業誌」p.172 参照)。

(1990 年 5 月 10 日原稿受理, 1990 年 10 月 2 日採用決定) 